\title{
DISTRIBUTION OF CESTODES IN FARMED COMMON CARP (CYPRINUS CARPIO L., 1758) FROM CYPRINID AQUACULTURE IN MACEDONIA
}

\author{
Dijana Blazhekovikj - Dimovska ${ }^{1, *}$, Stojmir Stojanovski ${ }^{2}$, Stoe Smiljkov ${ }^{3}$ \\ ${ }^{1}$ Faculty of biotechnical sciences, University „St. Kliment Ohridski”, Bitola, N. Macedonia \\ ${ }^{2}$ Hidrobiological Institute, Ohrid, N. Macedonia \\ ${ }^{3}$ Institute of Biology, Faculty of Natural Science and Mathemathics, Skopje, N. Macedonia
}

\section{Current Trends in}

Natural Sciences

\begin{abstract}
The aim of this study was to determine the distribution of parasites of the class Cestoda in farmed common carp from the cyprinid aquaculture facilities in Macedonia. The representatives of the class Cestoda occur most often during the winter (in 3.47\% of examined fish), followed by spring (1.80\%) and autumn (1.73\%). They haven't been identified during the summer.

20 fish out of 958 totally examined were infected with cestodes, with a mean intensity of 6.40, and a prevalence of $1.76 \%$. In this study, the following parasite species were established: Caryophyllaeus fimbriceps, Bothriocephalus opsariichthydis and Ligula intestinalis (plerocercoid).

Based on the total number of fish examined from cyprinid aquaculture facilities in Macedonia, the highest prevalence from the class Cestoda is determined by Bothriocephalus opsariichthydis (1.04\%), followed by Caryophyllaeus fimbriceps and Ligula intestinalis with $0.55 \%$ each.

The highest mean intensity with parasites of the class Cestoda is determined by Caryophyllaeus fimbriceps (9.40), followed by Bothriocephalus opsariichthydis (6.30) and Ligula intestinalis (3.60).

The records of Caryophyllaeus fimbriceps in farmed common carp in the present study are considered as the first records for Macedonian aquaculture.
\end{abstract}

Keywords: aquaculture, cestodes, common carp, parasites.

\section{INTRODUCTION}

Representatives of the class Cestoda are endoparasitic platyhelminths with indirect life cycle, involving one or more intermediate hosts. Fish can be terminal or intermediate hosts. Adult cestodes usually parasitize the gastrointestinal tract while the larval stages are encapsulated in various tissues and organs in fish. According to Dick et al. (2006), adult forms show greater host specificity, compared to larval stages. Adult cestodes in the gastrointestinal tract can cause mechanical impairment or reduction of food absorption, but the most serious pathogenicity in host fish cause migratory larvae.

Some cestodes are highly pathogenic, causing mass morbidity and mortality, especially in young fish. Diseases in adult fish, given the localization of the parasite in intestines, are manifested by damage and atrophy of the genitals, liver and spleen, intestine inflammation, poor food consumption, weight loss, anemia and eventual death. 
The aim of this study was to determine the distribution of parasites of the class Cestoda in farmed common carp from the cyprinid aquaculture facilities in Macedonia.

\section{MATERIALS AND METHODS}

This study was carried out by seasons, in a period of three years. A total of 958 samples of common carp (Cyprinus carpio) from the cyprinid aquaculture facilities in Macedonia including fish farms and cage systems on reservoirs, were examined for parasitological investigations.

During the dissection, the intestines were examined using stereomicroscopes „Zeiss”- Stemi DV4 and „MBS 10", as well as light microscope „Reichart”, at Laboratory for fish diseases in Hydrobiological Institute in Ohrid (Macedonia).

The observation under scanning electron microscopy (SEM) was made at Laboratory of electron and confocal microscopy in Faculty of biology, University of Warsaw (Poland). Total number of parasites was determined directly by numerical count. The number of fish examined, fish infected, prevalence and mean intensity (total and by seasons) are given in tables.

Classical epidemiological variables (prevalence and mean intensity) were calculated according to Bush et al. (1997). The parasite specimens were identified using reference keys of Bauer (1985, 1987) and Gussev (1983).

\section{RESULTS AND DISCUSSIONS}

During the parasitological examinations of the common carp from the cyprinid aquaculture facilities in Macedonia, a total of 958 fish samples were examined, from which parasite infestation with representatives of the class Cestoda was determined in 20 fish, with a total prevalence of $1.76 \%$ and a mean intensity of 6.40 (Table 1).

Table 1. Total prevalence and mean intensity with parasites of the class Cestoda in common carp from cyprinid aquaculture facilities in Macedonia

\begin{tabular}{||c||c|c|c|c|}
\hline Parasites & $\begin{array}{c}\text { Number of } \\
\text { examined fish }\end{array}$ & $\begin{array}{c}\text { Number of } \\
\text { infected fish }\end{array}$ & $\begin{array}{c}\text { Mean } \\
\text { intensity }\end{array}$ & Prevalence \\
\hline \hline Class Cestoda & 958 & 20 & 6.40 & $1.76 \%$ \\
\hline
\end{tabular}

Whereby from the class Cestoda, three parasite species were identified in common carp: Caryophyllaeus fimbriceps, Bothriocephalus opsariichthydis and Ligula intestinalis (plerocercoid). Based on the total number of fish examined from cyprinid aquaculture facilities in Macedonia, the highest prevalence from the class Cestoda is determined by Bothriocephalus opsariichthydis (1.04\%), followed by Caryophyllaeus fimbriceps and Ligula intestinalis with $0.55 \%$ each.

The highest mean intensity with parasites of the class Cestoda is determined by Caryophyllaeus fimbriceps (9.40), followed by Bothriocephalus opsariichthydis (6.30) and Ligula intestinalis (3.60). (Table 2)

Table 2. Total prevalence and mean intensity with determined cestode species in common carp from the cyprinid aquaculture facilities in Macedonia

\begin{tabular}{|c|c|c|c|c|}
\hline \multicolumn{2}{|r|}{ Parasite species } & Number of infected fish & Mean intensity & Prevalence $(\%)$ \\
\hline 1 & Caryophyllaeus fimbriceps & 5 & 9.40 & 0.55 \\
\hline 2 & Bothriocephalus opsariichthydis & 10 & 6.30 & 1.04 \\
\hline 3 & Ligula intestinalis & 5 & 3.60 & 0.55 \\
\hline
\end{tabular}


Current Trends in Natural Sciences

Vol. 10, Issue 19, pp. 427-439, 2021

https://doi.org/10.47068/ctns.2021.v10i19.057

Current Trends in Natural Sciences (on-line)

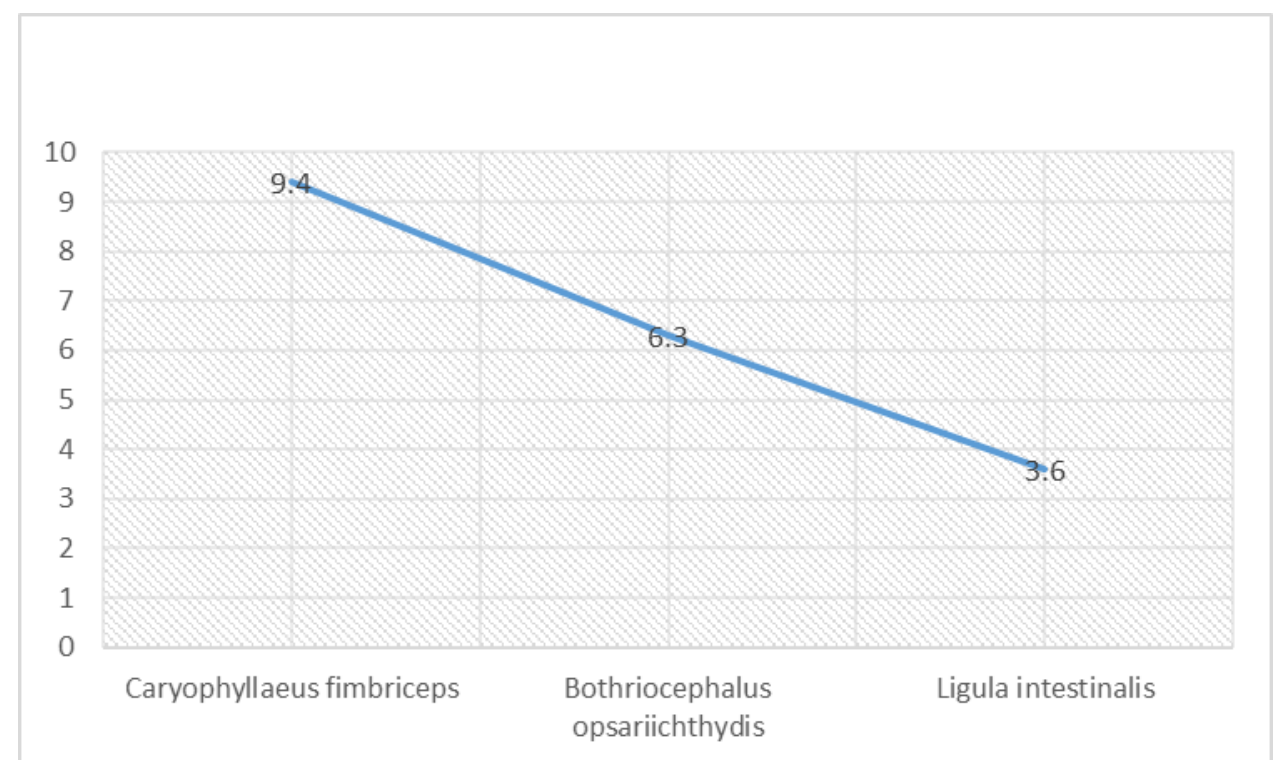

Figure 1. Total mean intensity with determined cestode species in cyprinid aquaculture facilities in Macedonia

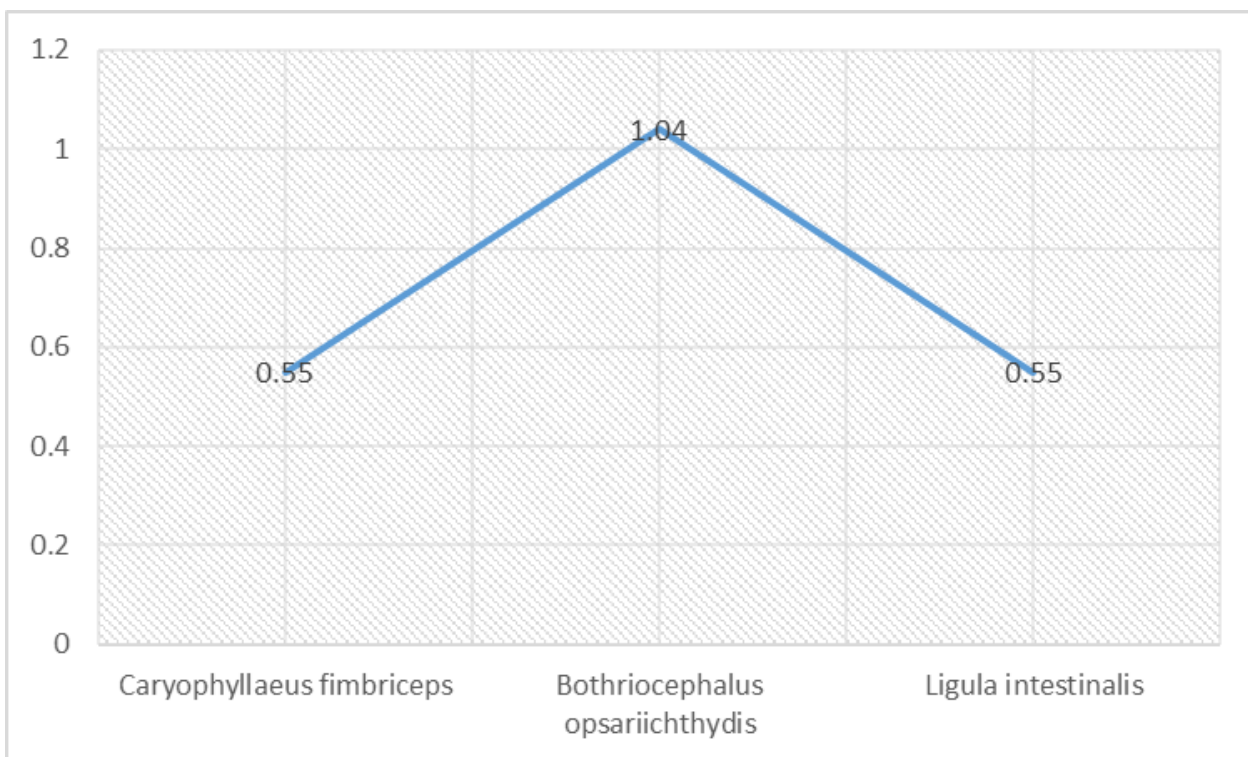

Figure 2. Total prevalence with determined cestoda species in cyprinid aquaculture facilities in Macedonia

The representatives of the class Cestoda most often occur during the winter (in $3.47 \%$ of examined fish), followed by spring (1.80\%) and autumn (1.73\%). 20 fish out of 958 totally examined were infected with cestodes, and by seasons, the number of infected fish was: spring - 5; summer - 0 ; autumn - 5 and winter - 10 fish. 
Table 3. Prevalence (P) and mean intensity $(I)$ with parasites from the class Cestoda in common carp from the cyprinid aquaculture facilities in Macedonia, by seasons

\begin{tabular}{|c|c|c|c|c|c|c|c|c|}
\hline \multirow{2}{*}{ Parasite species } & \multicolumn{2}{|c|}{ Spring } & \multicolumn{2}{|c|}{ Summer } & \multicolumn{2}{|c|}{ Autumn } & \multicolumn{2}{|c|}{ Winter } \\
\hline & $\mathbf{I}$ & $\mathbf{P}(\%)$ & $\mathbf{I}$ & $\mathbf{P}(\%)$ & I & $\mathbf{P}(\%)$ & I & $\mathbf{P}(\%)$ \\
\hline Caryophyllaeus fimbriceps & 9.40 & 0.44 & l & l & l & l & l & l \\
\hline Bothriocephalus opsariichthydis & l & I & l & l & 8.20 & 0.44 & 4.40 & 0.44 \\
\hline Ligula intestinalis & I & I & I & I & I & I & 3.60 & 0.44 \\
\hline
\end{tabular}

During our research, the dynamics of parasite occurrence in fish varies depending on the parasite species and the season:

- 1 cestode species, Caryophyllaeus fimbriceps, was determined in common carp in the spring;

- 1 cestode species, Bothriocephalus opsariichthydis, was determined in common carp in the autumn;

- 2 cestode species, Bothriocephalus opsariichthydis and Ligula intestinalis, were determined in common carp in the winter.

With all identified species (Caryophyllaeus fimbriceps, Bothriocephalus opsariichthydis and Ligula intestinalis) from the class Cestoda, regardless of the season, the prevalence was $0.44 \%$. On the other hand, the highest mean intensity (9.40) was determined with Caryophyllaeus fimbriceps in spring and the lowest (3.60) with Ligula intestinalis in winter (Table 3).

In our research, Caryophyllaeus fimbriceps was found in the intestines of 5 specimens of common carp in a fish farm Zhabeni in spring, with a prevalence of $0.44 \%$, and a mean intensity of 9.40. The records of Caryophyllaeus fimbriceps in farmed common carp in the present study are considered as the first records for Macedonian aquaculture.

According to the data from the previous parasitological researches in Macedonia, Caryophyllaeus fimbriceps was first determined by Stojanovski (1997) in common carp from Lake Ohrid, with a prevalence of $0.20 \%$ and mean intensity of 3.33. According to literary reviews from the other countries and the world, data on the occurrence of Caryophyllaeus fimbriceps in common carp has been reported by Hacmanjek et al. (1998) in a carp fishpond in Croatia and by Sattari (1996) and Khara et al. (2011) in carp fishponds in Iran.

Parasites of the genus Caryophyllaeus cause parasitic diseases of the digestive tract in cyprinid fish. According to Bauer (1987), Caryophyllaeus fimbriceps is an intestinal parasite in common carp, and less common in other species cyprinid fish. It cause mortality in carp offspring during invasions with 20 - 40 parasites. Adult fish are usually parasite carriers and they have a lower mean intensity. Adult parasites lay eggs in the intestines of fish, which through the excreta reach the water and are introduced by the intermediate hosts - oligochaetes of the genus Tubifex. In the intestines of oligochaetes, eggs hatch larvae that during 2.5 - 3 months, in the body cavity develop up to infectious stage - procercoid.

According to Vasiljkov (1983), fish are most often infested with Caryophyllaeus fimbriceps during the month of April, when entering an invaded intermediate host, and already in May, sexually mature forms of the parasite are found in the intestines of fish. This finding is consistent with our findings on this parasite in spring season. With the cessation of the diet, in the autumn, it also decreases fish infestation. The changes caused by Caryophyllaeus fimbriceps can be associated with the reproductive cycle and the physiological stage of the carp, water temperature and nutrient fish activity. 


\begin{tabular}{|c|c|}
\hline & $\begin{array}{c}\text { Current Trends in Natural Sciences } \\
\text { Vol. 10, Issue 19, pp. 427-439, } 2021 \\
\text { https://doi.org/10.47068/ctns.2021.v10i19.057 }\end{array}$ \\
\hline $\begin{array}{l}\text { Current Trends in Natural Sciences (on-line) } \\
\text { ISSN: 2284-953X } \\
\text { ISSN-L: 2284-9521 }\end{array}$ & $\begin{array}{r}\text { Current Trends in Natural Sciences (CD-Rom) } \\
\text { ISSN: 2284-9521 } \\
\text { ISSN-L: 2284-9521 }\end{array}$ \\
\hline
\end{tabular}

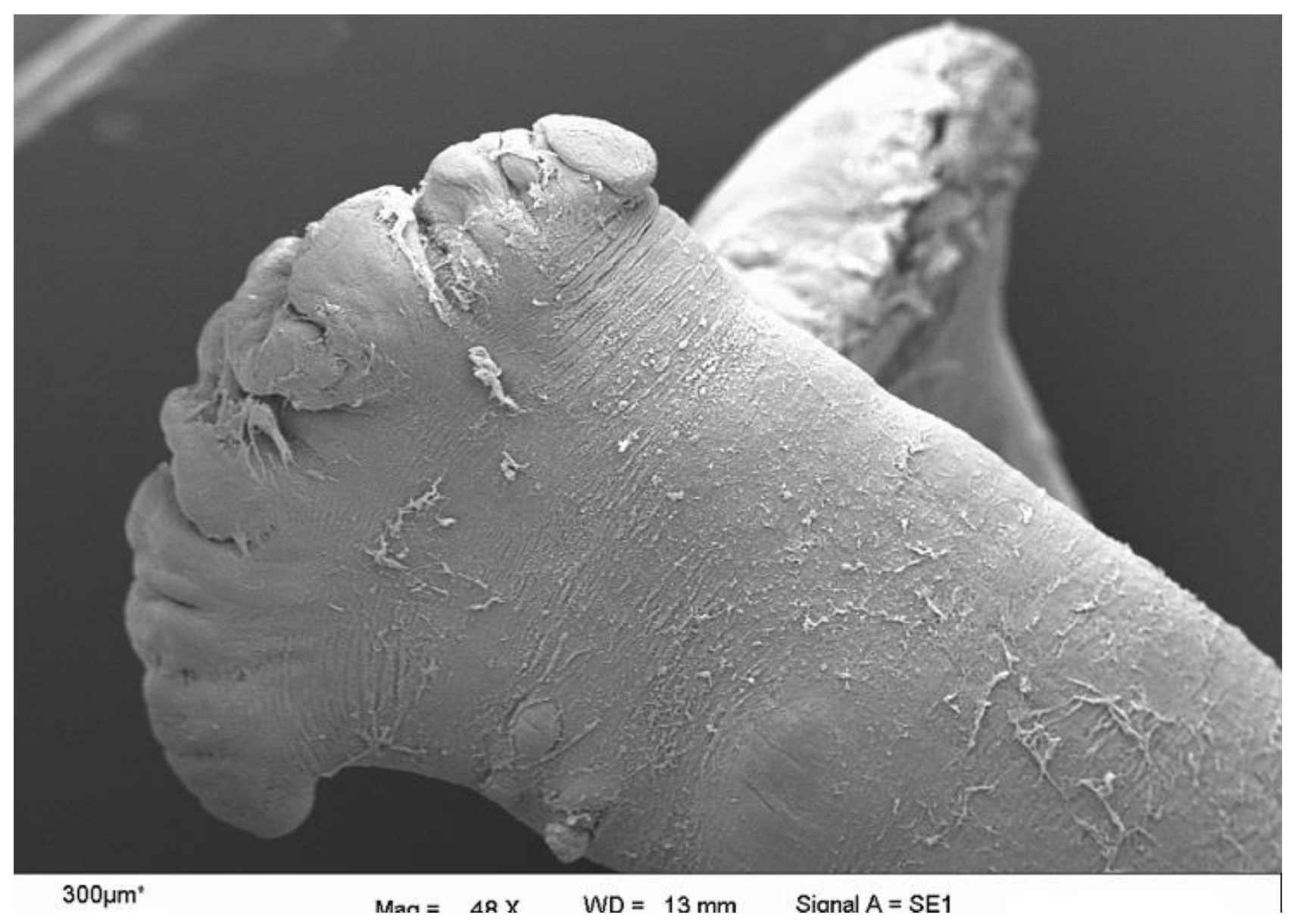

Figure 3. Caryophyllaeus fimbriceps - scolex $(48$ x) (original)

In our research, Bothriocephalus opsariichthydis was found in intestines of 10 specimens of common carp in cage farms on Tikvesh reservoir in autumn and Mladost reservoir in winter.

This is a first finding of Bothriocephalus opsariichthydis in common carp from the Mladost reservoir. The total prevalence with Bothriocephalus opsariichthydis in common carp was $1.04 \%$, while the total mean intensity, 6.30 . The prevalence by seasons was: autumn $-0.44 \%$ and winter $0.44 \%$; while the mean intensity, autumn -8.20 and winter $-4,40$.

Bothriocephalus opsariichthydis is white cestode, with a body length of $5-14 \mathrm{~cm}$, and a width of $1.6-2.1 \mathrm{~mm}$. It is a cestode which due to the great adaptability (eurythremia, short life cycle and a wide range of intermediate and terminal hosts) is prevalent around the world and is quite common parasite in many freshwater fish species (Koyun, 2001). Common carp and grass carp are in principle native hosts for Bothriocephalus opsariichthydis, but it has an extremely low degree of specificity towards a host, where according to Dove \& Fletcher (2000), it is found in fish of 12 families and 6 orders, worldwide. 

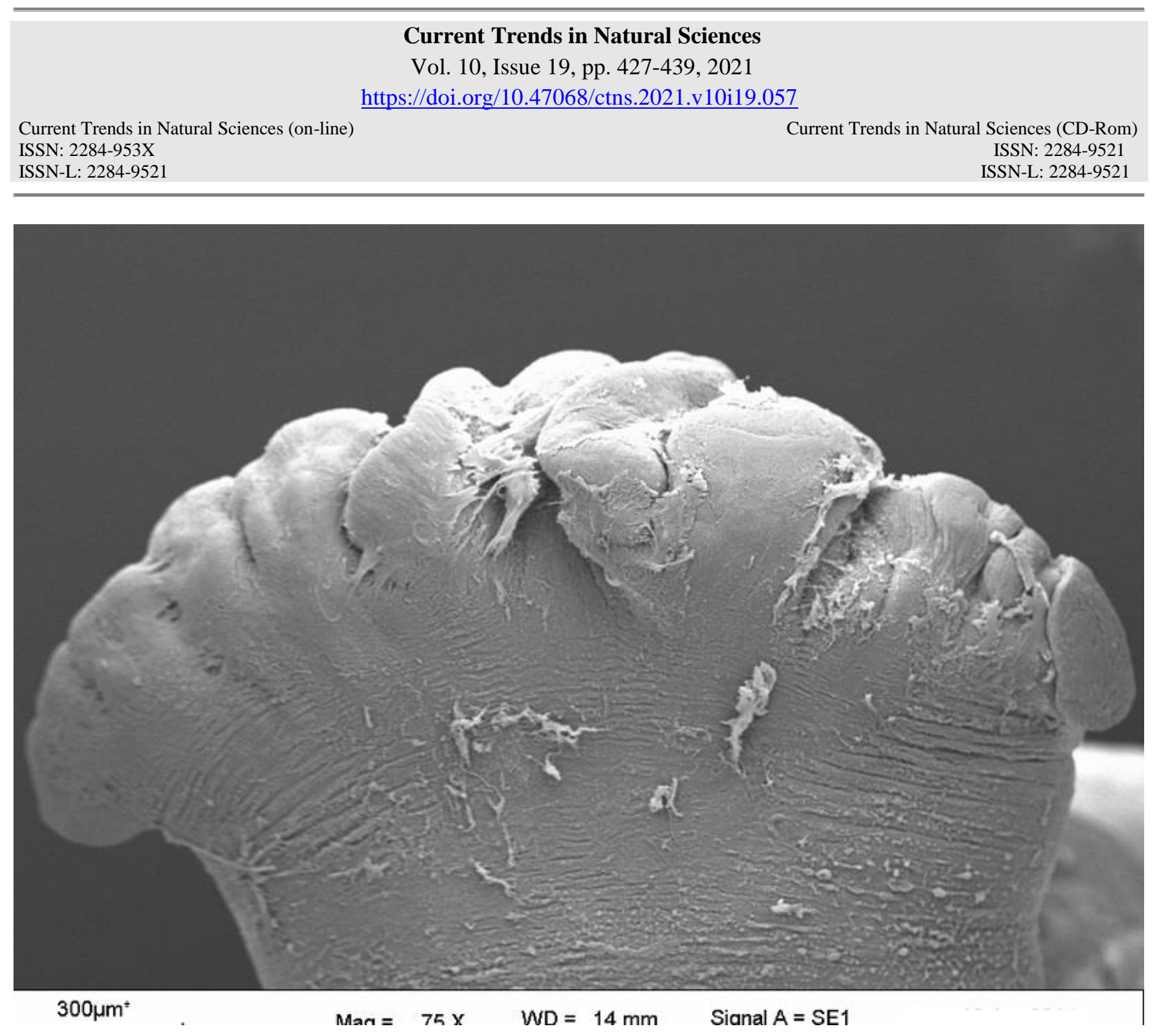

Figure 4. Caryophyllaeus fimbriceps - scolex $(75 \mathrm{x})$

According to the data from the the previous parasitological researches in Macedonia, Bothriocephalus opsariichthydis was first determined by Hristovski (1983) in common carp from Lake Dojran and fishfarm Zhabeni. In addition, Hristovski et al. (2001, 2006) found this cestode in common carp from Lake Prespa, with a prevalence of 4.44\%, while Lees \& Hristovski (1982) and Hristovski (1986) identified this parasite in common carp from lakes in northern Greece. Stojanovski (1997) found Bothriocephalus opsariichthydis in common carp from Lake Ohrid, with a prevalence of $0.67 \%$ and a mean intensity of 1.82. The appearance of Bothriocephalus opsariichthydis in common carp from Tikvesh reservoir was determined by Hristovski et al. (2007). According to the literary reviews from other countries, this cestode in waters in Serbia was determined by Andrić (1984) and Cakić (1992), in carp fishfarms in Croatia by Kezić al. (1975) whose finding was the first for this country and Hacmanjek et al. (1998) which found the largest distribution with Bothriocephalus opsariichthydis during the months of April and May.

According to the literary reviews from the European countries and the worldwide, Radu et al., (2008) reported data on the presence of Bothriocephalus opsariichthydis in common carp from fishponds in Romania, Bozorgnia et al. (2012) found this cestode in a fishpond in Iran, while Kuperman et al. (2002) established a large distribution of this parasite in common carp in waters of southern California. 


\begin{tabular}{|c|c|}
\hline & $\begin{array}{c}\text { Current Trends in Natural Sciences } \\
\text { Vol. 10, Issue 19, pp. 427-439, } 2021 \\
\text { https://doi.org/10.47068/ctns.2021.v10i19.057 }\end{array}$ \\
\hline $\begin{array}{l}\text { Current Trends in Natural Sciences (on-line) } \\
\text { ISSN: 2284-953X } \\
\text { ISSN-L: 2284-9521 }\end{array}$ & $\begin{array}{r}\text { Current Trends in Natural Sciences (CD-Rom) } \\
\text { ISSN: 2284-9521 } \\
\text { ISSN-L: 2284-9521 }\end{array}$ \\
\hline
\end{tabular}

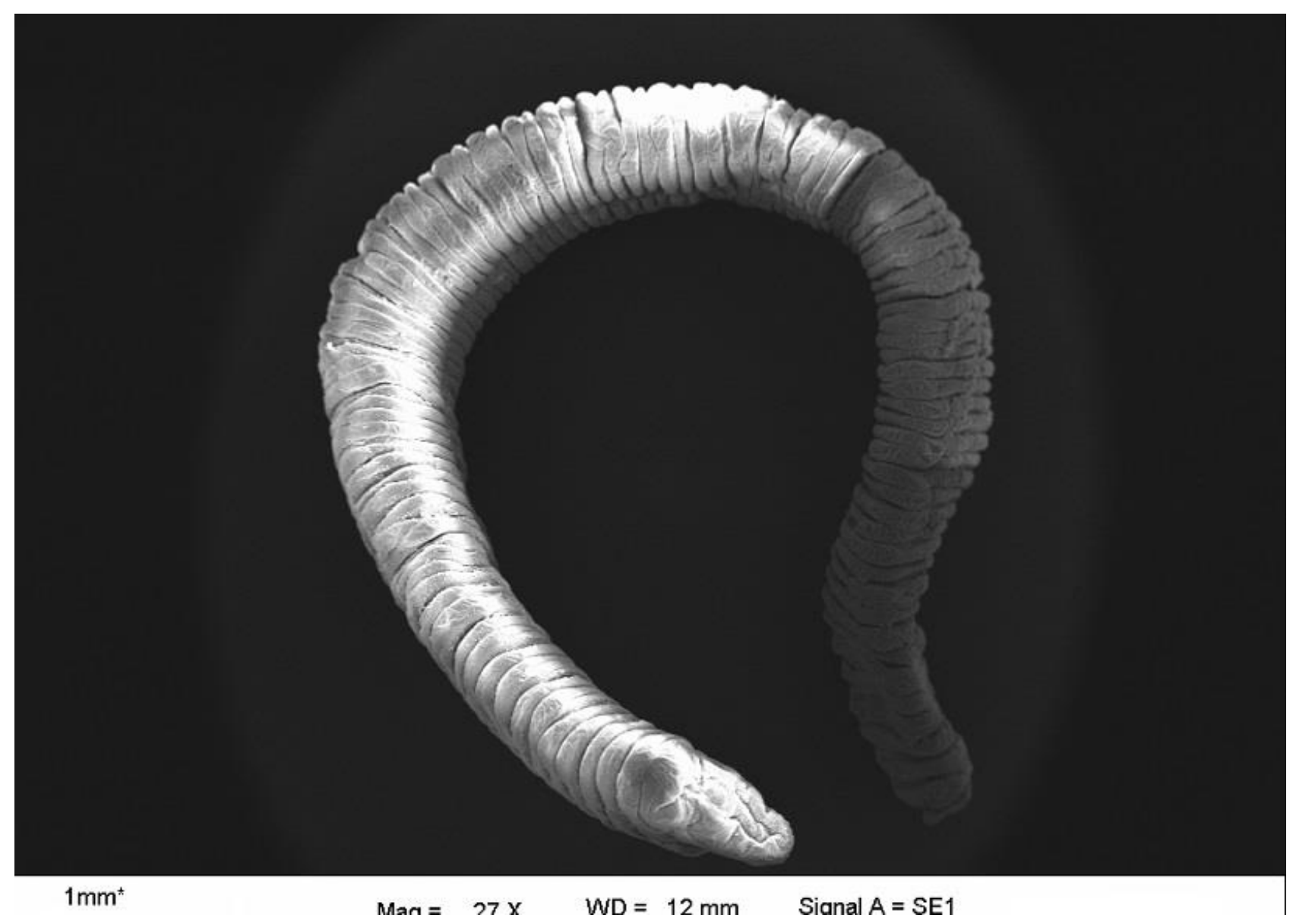

Figure 5. Bothriocephalus opsariichthydis - whole parasite (27 x) (original)

In Turkey, data on the occurrence of Bothriocephalus opsariichthydis in common carp have been reported by Oğuz et al. (1996) from Lake Uluabat; Aydoğdu et al. (1997, 2003) from Lake Iznik; Kir et al. (2004) from the lake Karacaören Dam; Öztürk (2005) from Lake Eber; Uzunay \& Soylu (2006) from the lake Sapanca; Kir \& Tekin Özan (2007) from Lake Kovada and Tekin-Özan et al. (2008) from Lake Beyşehir.

Hansen et al. (2007) found that Bothriocephalus opsariichthydis has less complex life cycle compared to many other tapeworms, requiring only one intermediate host before reaching the final host. Adult stage parasitizes in the intestines of fish. It absorbs nutrients through body cavity, competing with the host for food.

According to Marcogliese (2008) and Hansen et al. (2006), Bothriocephalus opsariichthydis causes reduced food intake, weight loss, slow growth, anemia, decreased condition, intestinal inflammation, altered activity of digestive enzymes and mortality in infected fish offspring.

During our research we found that there is a negative correlation between the abundance of Bothriocephalus opsariichthydis and the water temperature. 


\begin{tabular}{|c|c|}
\hline \multicolumn{2}{|c|}{$\begin{array}{c}\text { Current Trends in Natural Sciences } \\
\text { Vol. 10, Issue 19, pp. 427-439, } 2021 \\
\text { https://doi.org/10.47068/ctns.2021.v10i19.057 }\end{array}$} \\
\hline $\begin{array}{l}\text { Current Trends in Natural Sciences (on-line) } \\
\text { ISSN: 2284-953X } \\
\text { ISSN-L: 2284-9521 }\end{array}$ & $\begin{array}{r}\text { Current Trends in Natural Sciences (CD-Rom) } \\
\text { ISSN: 2284-9521 } \\
\text { ISSN-L: 2284-9521 }\end{array}$ \\
\hline
\end{tabular}

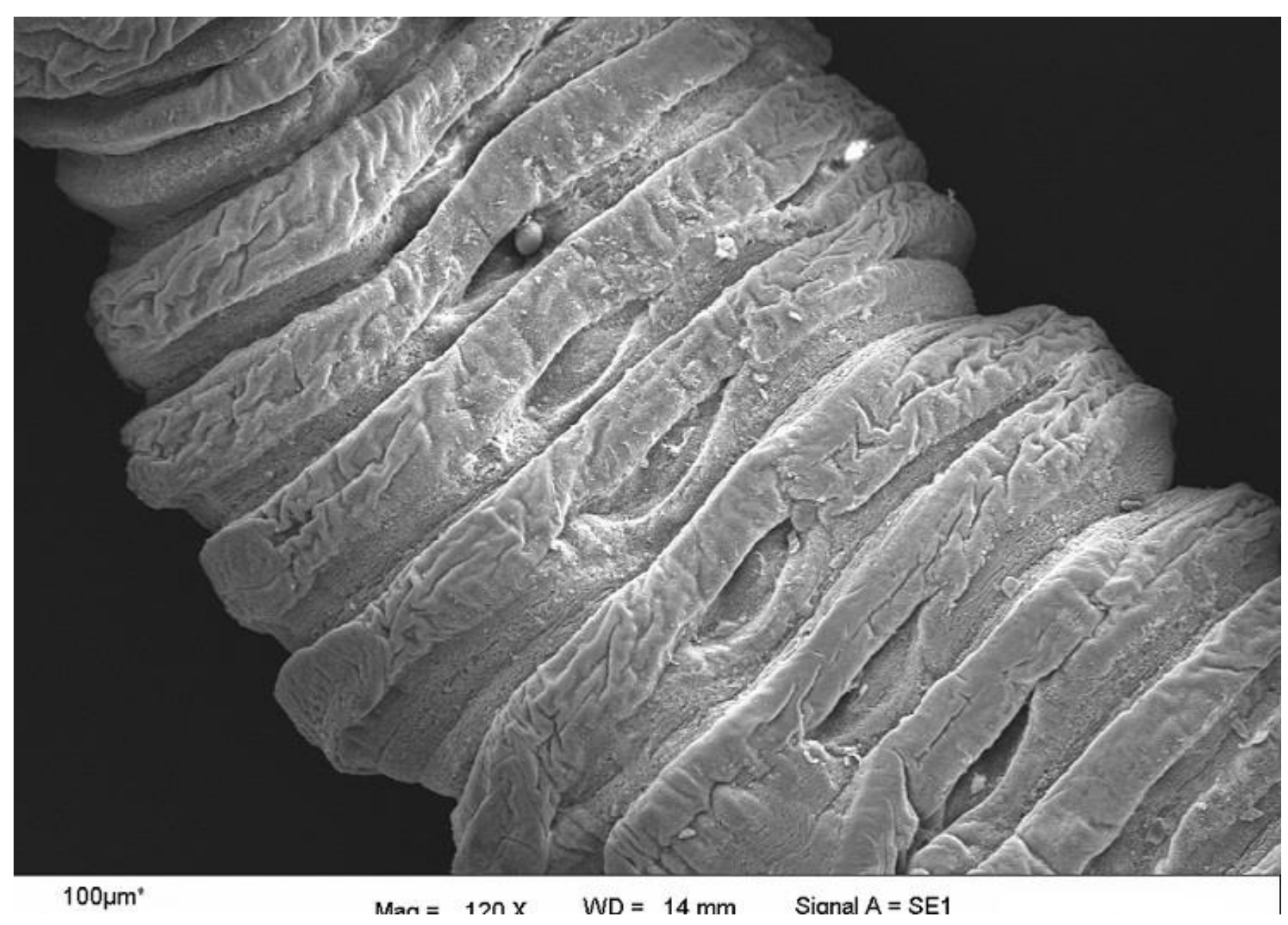

Figure 6. Bothriocephalus opsariichthydis - proglotids (120 x) (original)

In our research, Ligula intestinalis was found in the intestines of 5 specimens of common carp in a cage farm on Mladost reservoir, in winter. This is a first finding of Ligula intestinalis in common carp from the Mladost reservoir.

The prevalence with Ligula intestinalis in common carp was $0.44 \%$, while the mean intensity, 3.60. Ligula intestinalis is a cestode, with vaguely expressed segmentation, length $15-75 \mathrm{~cm}$ and width $0.5-1.5 \mathrm{~cm}$.

According to the data from the previous parasitological researches in Macedonia, Ligula intestinalis in common carp was first determined by Hristovski (1983) in Lake Prespa, Lake Ohrid, Tikvesh reservoir and the fish ponds Zhabeni and Bukri. Hristovski et al. (2001, 2006, 2012) found this cestode in common carp from Lake Prespa.

According to the literature reviews from the other countries, Ligula intestinalis was established by Cakić (1992) in cyprinid fish in waters in Serbia, while in fish population in the river Krka in Croatia by Valić et al. (2005). Hristovski $(1975,1982)$ published data on the presence of Ligula intestinalis in the waters of Prespa and Kostur Lakes in Greece. In Turkey, data on the appearance of Ligula intestinalis in common carp was reported by Becer \& Kara (1998) from Lake Kovada and Kir et al. (2004) from the lake Karacaören Dam. 


\section{Current Trends in Natural Sciences}

Vol. 10, Issue 19, pp. 427-439, 2021

https://doi.org/10.47068/ctns.2021.v10i19.057

Current Trends in Natural Sciences (on-line)

ISSN: 2284-953X

Current Trends in Natural Sciences (CD-Rom)

ISSN: 2284-9521

ISSN-L: 2284-9521

ISSN-L: 2284-9521

Ligula intestinalis in the stage of plerocercoid, causes disease in fish called ligulosis. The development of Ligula intestinalis takes place through two intermediate hosts. According to Loot et al. (2001), Ligula intestinalis has a complex life cycle that includes an adult form that parasitizes in fish-eating birds, eggs that are laid by birds and hatched copepods consumed by planktonic fish, especially cyprinids. Plerocercoid larva is always free in the body cavity of the host fish, where causes severe damages, reproductive retardation (Loot et al., 2002; Morgan, 2003) and behavioral changes (Loot et al., 2001; Brown et al., 2002), making fish more susceptible to predator birds.

Kakačeva-Avramova (1983) states that the development of plerocercoids up to invasive state, in the fish abdominal cavity lasts 12 - 14 months. Ultimate hosts - birds become infected by eating the dead or weakened invaded fish. In fact, the cycle ends as soon as the infected fish is eaten by fisheating birds, mostly of the genus Larus. In the birds intestine, plerocercoids develop into sexually mature parasites in about 3 days. This parasite lives only a few days in the digestive tract of birds, as long as does not lay eggs and then dies.

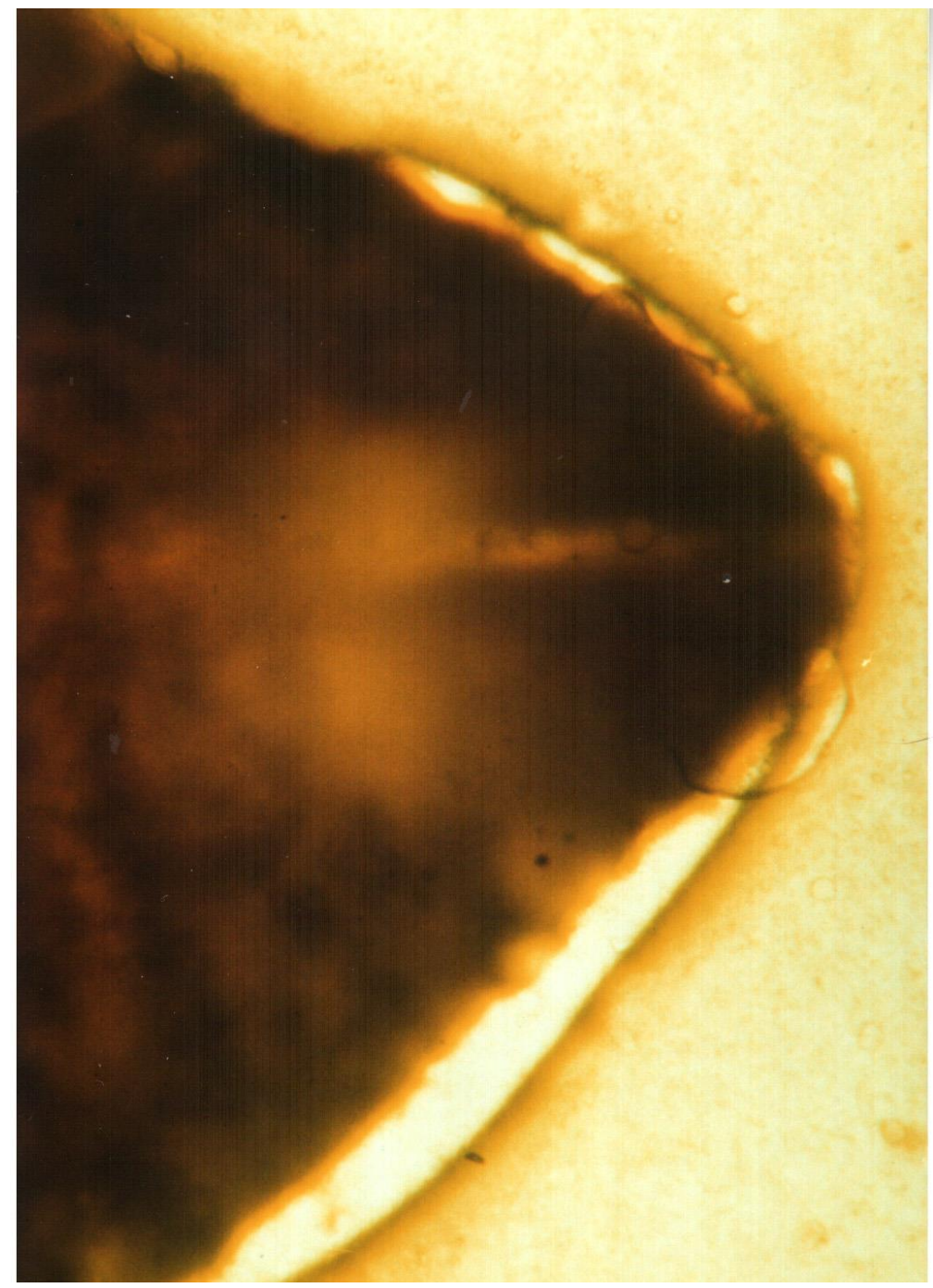

Figure 7. Ligula intestinalis (plerocercoid)- anterior part (original) 


\begin{tabular}{|c|c|}
\hline & \\
\hline $\begin{array}{l}\text { Current Trends in Natural Sciences (on-line) } \\
\text { ISSN: 2284-953X } \\
\text { ISSN-L: } 2284-9521\end{array}$ & $\begin{array}{l}\text { Current Trends in Natural Sciences (CD-Rom) } \\
\text { ISSN: 2284-9521 } \\
\text { ISSN-L: 2284-9521 }\end{array}$ \\
\hline
\end{tabular}

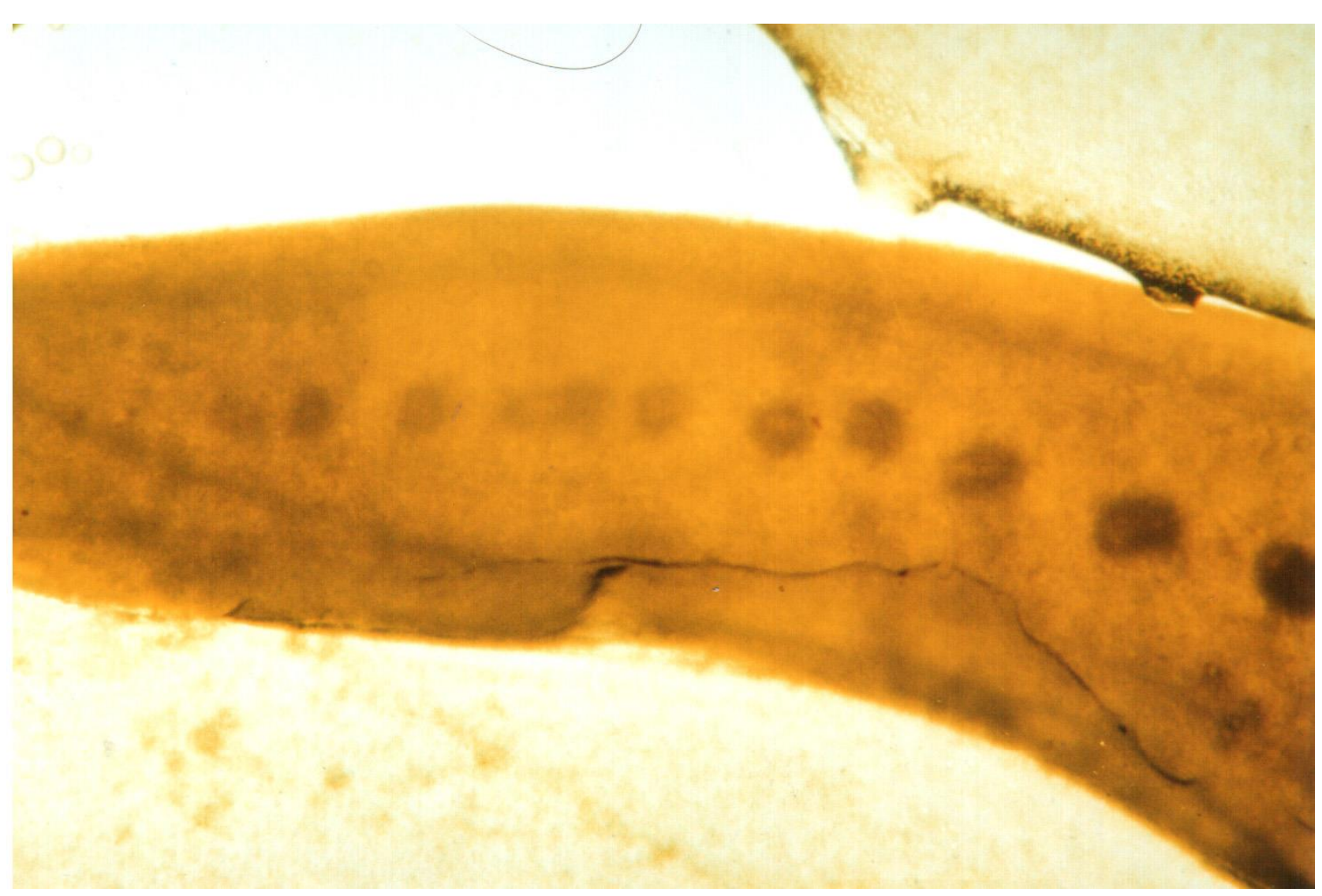

Figure 8. Ligula intestinalis (plerocercoid) - posterior part (original)

\section{CONCLUSIONS}

In our research, three parasites species have been identified from the class Cestoda: Caryophyllaeus fimbriceps, Bothriocephalus opsariichthydis and Ligula intestinalis (plerocercoid).

Based on the total number of fish examined from cyprinid aquaculture facilities in Macedonia, the highest prevalence from the class Cestoda is determined by Bothriocephalus opsariichthydis (1.04\%), followed by Caryophyllaeus fimbriceps and Ligula intestinalis with $0.55 \%$ each.

The highest mean intensity with parasites of the class Cestoda is determined by Caryophyllaeus fimbriceps (9.40), followed by Bothriocephalus opsariichthydis (6.30) and Ligula intestinalis (3.60).

The records of Caryophyllaeus fimbriceps in farmed common carp in the present study are considered as the first records for Macedonian aquaculture.

Cestode infections are greatly influenced by the season, which is basically correlated with the ecology and physiology of the fish. There are monthly variations in the prevalence and mean intensity of cestode infestation in fish. The period from November to March is the most sensitive period of the year when fish cestode are most prevalent. It arises as a result of stocking density, water depth, temperature, physicochemical parameters and maintenance of good hygiene practice. There is no doubt that the cestode fauna correlates with the diet of the host. Carp mainly feed on detritus, plankton, algae, plants, insect larvae, worms, shrimp, snails, etc. The type and the 
composition of carp diet is a very important parameter for the formation of cestode fauna in this fish and is significantly influenced by local environmental conditions.

Most protozoa, monogenic trematodes and parasitic copepods have a direct life cycle, i.e they are transmitted directly from fish to fish. However, the largest number of cestodes species use one or two intermediate hosts to complete their life cycle. If the intermediate or terminal host, or species closely related to them, are absent in the environment, the parasite will not be able to complete its life cycle, in which case there would be no risk of infestation.

The diet and fish condition also allows the closure of the development cycle of a significant number of cestode species. If the number of parasites (prevalence and mean intensity) is not particularly high, the reason for this is, among other factors, the relatively good water quality and good fish condition.

\section{REFERENCES}

Andrić, M. (1984). Endohelminth fish of Obedska Bara. Monogrpahy. Republic Science Association of Serbia, Belgrade.

Aydoğdu, A., Yıldırımhan, H.S., Altunel, F.N. (1997). An investigation on some metazoan parasites of common carp (Cyprinus carpio L.,) in İznik Lake. Turkiye Parazitol. Derg., 21 (4), 442-445.

Aydoğdu,, A., Kostadinova A., Fernandez, M. (2003). Variations in the distribution of parasites in the common carp, Cyprinus carpio, from Lake İznik, Turkey: population dynamics related to season and host size. Helminthologia, $40(1), 33-40$.

Bauer, O.N. (1985). Opredelitelj parazitov presnovodnih ryb fauni SSSR. Tom II (Parazitiţeskie mnogokletoţnie. Pervaja ţast). Akademia Nauk SSSR. Izdateljstvo "Nauka", Leningrad. [Identifier of parasites of freshwater fish fauna of the USSR. Volume II (Parasitic multicellular. First honor]. Academy of Sciences of the USSR. Science Publishing House, Leningrad).

Bauer, O.N. (1987). Opredelitelj parazitov presnovodnih ryb fauni SSSR. Tom III (Parazitiţeskie mnogokletoţnie. Vtoraja ţast). Akademia Nauk SSSR. Izdateljstvo "Nauka", Leningrad. [Identifier of parasites of freshwater fish fauna of the USSR. Volume III (Parasitic multicellular. Second honor). Academy of Sciences of the USSR. Science Publishing House, Leningrad].

Becer, Z.A., Kara, D. (1998). An investigation on population structure and parasites of common carp (Cyprinus carpio L. 1758), which were caught in Kovada Lake. Acta Parasitologica Turcica, 22 (2), 199-203.

Bozorgnia, A., Youssefi,, M.R., Barzega,r M., Hosseinifard S.M., Ebrahimpour, S. (2012). Biodiversity of Parasites of Fishes in Gheshlagh (Vahdat) Reservoir, Kurdistan Province, Iran. World Journal of Fish and Marine Sciences, 4 (3), 249-253.

Brown, S. P., Loot, G., Teriokhin, A., Brunel,, A., Brunel C., Guegan, J.F. (2002). Host manipulation by Ligula intestinalis: a cause or consequence of parasite aggregation. International Journal for Parasitology, 32, 817-824.

Bush, A.O, Lafferty, K.D., Lotz, J.M., Shostak, A.W. (1997). Parasitology meets ecology on its own terms: Margolis et al. Revisited. J. Parasitology., 83, 575 - 583.

Cakić, P. (1992). Fish parasites in the waters of the Sjeničko-Pešterske plateau and the possibilities of their control. $\mathrm{PhD}$ thesis. Veterinary Faculty, University of Belgrade, Serbia.

Dick, T. A., Chambers, C., Isinguzo, I. (2006). Cestoidea (Phylum Platyhemlinthes). In: Fish diseases and disorders. Protozoan and metazoan infections, Vol. 1. (Ed: Woo, P.T.K.), CAB International, Wallingford, UK, pp. 391 416.

Dove, A.D.M., Fletcher, A.S. (2000). The distribution of the introduced tapeworm Bothriocephalus acheilognathi in Australian freshwater fishes". J. Helminthol., 74, 121- 127.

Gussev, A. V. (1983). The methods of collection and processing of fish parasitic monogenean materials" (In Russian). Nauka. Leningrad. USSR. pp. 25 - 45.

Hacmanjek, M., Tomec, M., Teskeređić, E.,Teskeređić, Z., Čož-Rakovac, R., Topić Popović, N. (1998). Carp cestodes and water quality in carp ponds. 39th Croatian Symposium on Agriculture with International Participation, pp. 250-251.

Hansen, S. P., Choudhury, A., Cole, R. A. (2007). Evidence of experimental postcyclic transmission of Bothriocephalus acheilognathi in bonytail chub (Gila elegans). Journal of Parasitology, 93, 202-204. 
Hansen, S.P., Choudhury, A., Heise, D.M., Ahumada J.A., Hoffnagle, T.L., Cole, R.A. (2006). Experimental infection of the endangered bonytail chub (Gila elegans) with the Asian fish tapeworm (Bothriocephalus acheilognathi): impacts on survival, growth, and condition”. Can. J. Zool., 84, 1383-1394

Hristovski, N. (1975). Endohelminths of cyprinid fish of Lake Prespa. Master thesis. Faculty of natural sciences, University of Novi Sad, Serbia.

Hristovski, N. D. (1982). Endohelminths of some fish species of Kastoria Lake (Greece). VI Biology Congress in Yugoslavia, Novi Sad, Serbia. Book of proceeding 1, 2 - 22.

Hristovski, N. D. (1983). Fauna of endohelminths fish in the lakes of SR Macedonia. PhD thesis. Faculty of natural sciences, University in Novi Sad, Serbia.

Hristovski, N. (1986). The helminth fauna from some lakes from North Greece:. V International Helminthological Symposium. Helminths, Helminthoses, Environment. Abstracts of reports. 42, Košice, Czechoslovakia.

Hristovski, N., Stojanovski, S., Cakić, P., Hristovski, M. (2001). Parasite fauna of the common carp (Cyprinus carpio Linnaeus, 1758) from the Prespa Lake, Macedonia. Journal of Animal Sciences, 5, 53-56.

Hristovski, N., Stojanovski, S., Baker, R.A., Petrovic, Z., Rusinek, O., Cakić, P. (2006). Parasite fauna of the fishes from Lake Prespa and life cycle of economically important and most frequently found parasite species. Monography. Faculty of biotechnical sciences. Bitola, Macedonia.

Hristovski, N., Stojanovski, S., Talevski, T., Blažeković - Dimovska, D. (2012). The fish parasite fauna and the fish of Lake Prespa. Monography. National and University library. University "St. Kliment Ohridski". Bitola, Macedonia.

Hristovski, M., Cvetkovic, A., Stojanovski, S. (2007). Investigation of cage carp diseases in Lake Tikves in 2005-2006. III International Conference of Fisheries, Belgrade, Serbia.

Kakačeva-Avramova, D. (1983). Helminths of freshwater fish in Bulgaria. Publishing House of the Bulgarian Academy of Sciences, Sofia, Bulgaria.

Kezić, N., Fijan, N., Kajgana, Lj. (1975). Vet. Arhiv 45, pp. 289-291.

Khara, H., Sattari, M., Nezami,, Sh., Mirhasheminasab S. F., Mousavi, S. A., Ahmadnezhad, M. (2011). Parasites of some bonyfish species from the Boojagh wetland in the southwest shores of the Caspian Sea, Caspian J. Env. Sci., 9 (1), 47-53.

Kır, İ., Ayvaz, Y., Barlas, M., Tekin-Özan, S. (2004). Seasonal distribution and effect of parasites on carp (Cyprinus carpio L., 1758) inhabiting the Karacaören Dam Lake. Turkiye Parazitol Derg, 28(1), 45-49.

Kir, I., Tekin Özan, S. (2007). Helminth Infections in common carp, Cyprinus Carpio L., 1758 (Cyprinidae) from Kovada Lake (Turkey). Türkiye Parazitoloji Dergisi, 31 (3), 232-236.

Koyun, M. (2001). The helminthofauna of some fishes in Enne Dam Lake. PhD thesis. Medical Institution, Uludağ University, Bursa, Turkey.

Kuperman, B.I., Matey, V.E., Warburton, M.L., Fisher, R.N. (2002). Introduced parasites of freshwater fish in Southern California, USA, The Tenth International Congress of Parasitology, Vankouver, Canada.

Lees, E., Hristovski, N. (1982). The helminth fauna of fish in Lake Lagadin, Greece. Molecular and Biochemical Parasitology. Parasites - their world and ours. ICOPA V. Elsevier Biomedical press. pp. 310, Amsterdam.

Loot, G., Brosse, S., Lek, S., Guegan, J.F. (2001). Behaviour of roach (Rutilus rutilus L.) altered by (Cestoda: Pseudophyllidea): a field demonstration. Freshwater Biology 46, 1219-1227.

Loot, G., Poulin, R., Lek, S., Guegan, J.F. (2002). The differential effects of Ligula intestinalis (L.) plerocercoids on host growth in three natural populations of roach, Rutilus rutilus (L.). Ecology of Freshwater Fish, 11, 168-177.

Marcogliese, D.J. (2008). First report of the Asian fish tapeworm in the great lakes. J. Great Lakes Res., 34, 566-569.

Morgan, D. L. (2003). Distribution and biology of Galaxias truttaceus (Galaxiidae) in south-western Australia, including first evidence of parasitism of fishes in Western Australia by Ligula intestinalis (Cestoda). Environmental Biology of Fishes, 66, 155-167.

Oğuz, M.C., Öztürk, M.O., Altunel, F.N., Ay, Y.D. (1996). A parasitological investigation on common carp (Cyprinus carpio L., 1758) caugth in Uluabat Lake. Turkiye Parazitol Derg, 20(1), 97-103.

Öztürk, M. (2005). An investigation of metazoan parasites of common carp (Cyprinus carpio L.) in Lake Eber, Afyon, Turkey. Turkiye parazitolojii dergisi, 29(3), 204-210.

Radu, D., Oprea, L., Nicolae, C. G. (2008). Comparative analyses concerning parasitic diversity of common carp and koi carp. Zootehnie si Biotehnologii, 41 (2).

Sattari, M. (1996). Parasites of some bonyfish species of Anzali wetland from the southwest of the Caspian Sea", [In Persian], Report to the University of Guilan, Iran, pp. 45-50. 


\section{Current Trends in Natural Sciences}

Vol. 10, Issue 19, pp. 427-439, 2021

https://doi.org/10.47068/ctns.2021.v10i19.057

Current Trends in Natural Sciences (on-line)

ISSN: 2284-953X

Current Trends in Natural Sciences (CD-Rom)

ISSN: 2284-9521

ISSN-L: 2284-9521

ISSN-L: 2284-9521

Stojanovski, S. (1997). Ecto and endoparasites of Ohrid Lake fish. Master thesis. Veterinary Faculty, University of Belgrade, Yugoslavia.

Tekin-Özan, Selda, Kir, İ., Barlas, M. (2008). Helminth Parasites of Common Carp (Cyprinus carpio L., 1758) in Beyşehir Lake and Population Dynamics Related to Month and Host Size. Turkish Journal of Fisheries and Aquatic Sciences, 8, 201-205.

Uzunay, E., Soylu, E. (2006). Metazoan parasites of carp (Cyprinus carpio Linnaeus, 1758) and vimba (Vimba vimba Linnaeus, 1758) in the Sapanca lake. Turk. Parazitol Derg., 30 (2), 141-50.

Valić, D., Kapetanović, D., Kurtović, B., Teskeređić, E. (2005). Fish parasites of the river Krka. Symposium "Krka River and National park Krka”, pp. 57-58.

Vasiljkov, G.V. (1983). Helminthiasis fish. Kolos Publishing House, Moscow, 45-50. 